\title{
Arbitration in EU Jurisdiction Regulation: Brussels I Recast and a New Proposal
}

\author{
Neil Dowers* and Zheng Sophia Tang** \\ DOI: $10.21827 / 5 a 86 a 8 a b b c 562$
}

\section{Keywords}

ARbitration; BRUSSELS I RECAST; EU JURISDICTION REGIME; ARBITRATION AGREEMENT

\begin{abstract}
The relationship between the European jurisdiction regime and arbitration is one of the areas generating confusion and disputes. The Brussels I Regulation clearly excludes arbitration from its scope to avoid conflicts with the New York Convention, but arbitration-related issues, such as the validity of arbitration agreements, either as an independent claim or an incidental question, frequently arise in courts. The scope of the Brussels I Regulation in terms of arbitration has been addressed by the Court of Justice of the European Union in a number of decisions, such as Marc Rich $v$ Societa Italiano Impianti, Van Uden, and Front Comor. None of them have provided a satisfactory answer. In order to provide clarification and to reconcile the European jurisdiction Regulation and the New York Convention, the Brussels I Recast has inserted a new recital specifically addressing the relationship between court jurisdiction and arbitration. This article aims to assess the effect of the new recital and whether it has appropriately resolved the difficult questions on the relationship between jurisdiction and arbitration in the European Union.
\end{abstract}

\section{Introduction}

When the judicial cooperation on jurisdiction and recognition and enforcement of judgments was established in the European Community, there was a clear intention that this Convention should only cover court proceedings, excluding arbitration. ${ }^{1}$ This exclusion was reaffirmed in the subsequent reforms and modernisation, including the 1978 Accession Convention, ${ }^{2}$ the Brussels I Regulation, ${ }^{3}$ and the recent Brussels I

Neil Dowers is a PhD Candidate, University of Edinburgh, UK.

** Zheng Sophia Tang is a Professor of Law and Commerce, Newcastle University, UK.

1 Article 1(4), Brussels Convention of 27 September 1968 on Jurisdiction and the Enforcement of Judgments in Civil and Commercial Matters (Consolidated Version) (1968) OJ C27/1 (Brussels Convention).

2 Article 1(4), Convention of Accession of 9 October 1978 of the Kingdom of Denmark, Ireland and the United Kingdom of Great Britain and Northern Ireland to the Convention on jurisdiction and enforcement of judgments in civil and commercial matters (1979) OJ L304/1.

3 Council of the European Union (EU), Council Regulation (EC) No 44/2001 of 22 December 2000 on jurisdiction and the recognition and enforcement of judgments in civil and commercial matters, (2001) OJ L12/1 (Brussels I Regulation). 
Recast. ${ }^{4}$ Arbitration is excluded because there are many international treaties on arbitration which may conflict with the European jurisdiction regime. ${ }^{5}$ In particular, the New York Convention on Recognition and Enforcement of Arbitral Awards (New York Convention $)^{6}$ is a very successful international framework, which applies to all Member States of the Brussels I regime. Article 71 of the Brussels I Regulation provides that the Regulation will not prejudice the treaty obligations of Member States under other international conventions in matters relating to jurisdiction, recognition and enforcement of judgments. Excluding arbitration from the Brussels I regime aims to avoid potential conflicts and to allow the Brussels I regime to perform alongside the New York Convention.

Arbitration is a private dispute resolution method, separate from court jurisdiction. However, arbitration can never work without the support and supervision of the court. The court's assistance is required to enforce arbitral awards, to appoint or remove arbitrators, to determine the place of arbitration, to provide preliminary ruling on substantive law, to extend the time limit to make awards, to incorporate arbitral awards into court judgments, to refer the parties to arbitration and to issue anti-suit injunctions to prevent the parties from breaching a valid arbitration agreement by commencing a foreign action. The court's supervision is also required to review arbitrators' jurisdiction, to scrutinise the arbitration procedure, to issue anti-arbitration injunctions, to restrain illegitimate arbitration processes, and to set aside arbitral awards in exceptional circumstances.

Therefore, it is hard to draw a clear-cut line between arbitration and court proceedings. Arbitration or arbitration-related issues frequently come before courts. The official reports on the Brussels Convention and the Court of Justice of the European Union (CJEU) case law fails to provide a systematic and consistent answer, which has led to tremendous uncertainties in practice. The European Union (EU) lawmakers have realised the difficulty and have made the relationship between arbitration and the EU jurisdiction regime one of the main issues that was examined in the review process that led to the reform of the jurisdiction regime, which resulted in the Brussels I Recast. The Brussels I Recast has maintained the same exclusion of arbitration but provided the guidance and explanatory notes in Recital 12, which aim to clarify the complexity and provide certainty in practice. This article, nevertheless, argues that the Brussels I Recast does not effectively remove all the practical problems arising out of the interaction between jurisdiction and arbitration. Three principles are proposed to provide an effective framework and to reconcile the conflict between Brussels I Recast and the New York Convention.

4 EU, Regulation (EU) No 1215/2012 of the European Parliament and the Council of 12 December 2012 on jurisdiction and the recognition and enforcement of judgments in civil and commercial matters (recast), (2012) OJ L351/1 (Brussels I Recast).

5 Jenard, P, Report on the Convention on Jurisdiction and the Enforcement of Judgments in Civil and Commercial Matters, (1979) OJ C59/1, 13.

6 United Nations, Convention on the Recognition and Enforcement of Foreign Arbitral Awards (1958) 330 UNTS 3 (New York Convention). 


\section{Brussels I Regulation}

\section{II.1. Exclusion of Arbitration from the Jurisdiction Regime}

The Brussels I Regulation provides: 'The Regulation shall not apply to...arbitration. ${ }^{.7}$ It does not clarify what is included in the word 'arbitration'. Arbitration may include arbitration proceedings, court proceedings ancillary to arbitration, disputes relating to arbitration, such as validity and scope of arbitration agreements, and disputes arguably subject to arbitration. A report by Jenard on the Brussels Conventions provides that

The Brussels Convention does not apply to the recognition and enforcement of arbitral awards; it does not apply for the purpose of determining the jurisdiction of courts and tribunals in respect of litigation relating to arbitration for example, proceedings to set aside an arbitral award; and, finally, it does not apply to the recognition of judgments given in such proceedings. ${ }^{8}$

This report provides a simple and non-exhaustive list of the matters covered by the word 'arbitration'. Those matters mentioned in the report are generally proceedings relating to arbitral awards or arbitration proceedings. Those issues are clearly included in the New York Convention and there is little dispute regarding their exclusion. The Schlosser Report has provided more detailed guidance. ${ }^{9}$ It recognised two conflicting opinions on the position of arbitration in the Brussels I regime. The first was proposed by the UK, suggesting the exclusion covers 'all disputes which the parties had effectively agreed should be settled by arbitration, including any secondary disputes connected with the agreed arbitration'. ${ }^{10}$ The other view suggests that the exclusion only aims to omit arbitration proceedings from the Brussels I regime. In other words, issues relating to the validity and existence of arbitration agreements should continue to be covered by the Brussels I regime. ${ }^{11}$

The variation leads to diversity in practice, where a matter is brought before a court and the court holds that the arbitration agreement is invalid and moves on to give judgment. The first interpretation suggests that this issue relates to arbitration and should be excluded from the Brussels I regime. The courts of other Member States, therefore, do not need to recognise and enforce this judgment. The second interpretation, on the contrary, includes this issue within the Brussels I regime. Other Member States are then obligated to enforce the court's judgment. ${ }^{12}$ The Schlosser Report states that the Brussels I regime does not cover court proceedings ancillary to arbitration proceedings, including a judgment determining the validity of an arbitration agreement and a decision to refer the parties to arbitration. ${ }^{13}$

\footnotetext{
Article 1(2)(d), Brussels I Regulation.

Jenard, supra nt 5.

9 Schlosser, P, Report on the Convention on the Association of the Kingdom of Denmark, Ireland and the United Kingdom of Great Britain and Northern Ireland to the Convention on jurisdiction and enforcement of judgments in civil and commercial matters and to the Protocol on its interpretation by the Court of Justice, (1979) OJ C59/71.

$10 \quad I d$, para 61.

11 Id, para 61; Hartley, TC, "The Brussels I Regulation on Arbitration", 63 International and Comparative Law Quarterly (2014) 843, 844.

12 Schlosser, supra nt 9, para 62.

13 Id, para 64; Hartley, supra nt 11, 844-847.
} 
It seems that a broad approach was proposed by the Schlosser Report. This approach can be justified for two reasons. First, since the exclusion of arbitration aims to reconcile the conflict between the European jurisdiction regime and the New York Convention, the scope of these two instruments should be mutually exclusive. That means everything covered in the New York Convention should be excluded from the scope of the Brussels I Regulation. The New York Convention primarily deals with recognition and enforcement of foreign arbitral awards, but it also covers other arbitration-related issues, including the validity of arbitration agreements and the court referring the parties to arbitration. ${ }^{14}$ Therefore, the Brussels I Regulation should also exclude arbitration related issues from its scope. Otherwise, some conflicts become inevitable. Second, besides the express scope, the Brussels I Regulation should not act to restrict the purpose of the New York Convention and the Member State's treaty obligation to protect arbitration and the parties' freedom to submit disputes to arbitration. If the Brussels I Regulation only excludes arbitration proceedings but includes matters relating to arbitration, it will hamper the purpose of the New York Convention. It could encourage the parties to submit their disputes subject to an arbitration agreement to the court. Parallel proceedings may exist between court proceedings and arbitration proceedings, which may result in irreconcilable judgments and arbitral awards. Enforcement of arbitral awards in the two systems, ie, the Brussels I Regulation and the New York Convention, causes conflicts that the European legislators aimed to avoid from the very beginning.

\section{II.2. Marc Rich $v$ Societa Italiano Impianti}

The first case that casts doubt on the arbitration exclusion is Marc Rich v Societa Italiano Impianti. ${ }^{15}$ In this case, a Swiss company and an Italian company concluded a contract for the sale of crude oil and agreed to submit their disputes to arbitration in London. The parties agreed that three arbitrators would be appointed, one chosen by each party who, together, would select the chair. After disputes arose, Impianti commenced litigation in Italy and Marc Rich commenced arbitration proceedings in London pursuant to the arbitration agreement. Impianti refused to participate in the London arbitration or to appoint an arbitrator according to their agreement. Marc Rich sought the assistance from the English court to appoint the second arbitrator and serve summons on Impianti. Impianti, however, argued that before the English court could appoint an arbitrator and serve summons, the English court must first assess the existence and the validity of the arbitration agreement, which is within the scope of the Brussels Convention. As Impianti first brought the dispute in Italy, where the validity of the arbitration agreement should be duly examined by the Italian court as a preliminary matter, both courts were seized to decide the same cause of action between the same parties. Impianti argued that the lis pendens doctrine of the Brussels Convention should apply and the English court, as the second seized court, should stay jurisdiction. ${ }^{16}$

This was the first time that the CJEU was seized to give a clear answer to the old conflict between the broad interpretation suggested by the UK and the narrow

14 Article II, New York Convention.

15 Court of Justice of the European Union (CJEU), Case C-190/89, Marc Rich v Societa Italiano Impianti [1991] ECR I-3855 (Marc Rich). For more on this case, see Munro, CM "Marc Rich v Impianti", 3 International Company and Commercial Law Review (1992) 116, 116; Hartley, TC, "The Scope of the Convention" 16 Edinburgh Law Review (1991) 529, 529; Kaye, P, "Forensic Submission as a Bar to Arbitration", 12 Civil Justice Quarterly (1993) 359.

16 Article 21, Brussels Convention (Article 27, Brussels I Regulation). 
interpretation suggested by the continental European countries. ${ }^{17}$ The CJEU confirmed the broad interpretation and, essentially, the approach suggested by the Schlosser Report. It provided that the Brussels Convention excludes arbitration 'in its entirety', including court proceedings in which the subject matter is arbitration. ${ }^{18}$ A related issue the CJEU answered was whether court proceedings where the subject matter is arbitration, only refer to those proceedings where arbitration was the principal issue. Do they also include proceedings where arbitration-related issues arise as an incidental question? The CJEU refused to provide different treatment to proceedings where arbitration is a primary issue and where arbitration is a preliminary incidental issue. Instead, the CJEU explained that since the court proceedings are regarding appointing an arbitrator, the subject matter of which is arbitration, it should be excluded from the scope of the Brussels Convention, regardless of whether the validity of the arbitration agreement is raised as a preliminary issue. ${ }^{19}$ This may also lead to the conclusion that if the main subject matter is not arbitration, even if ruling on the arbitration agreement is required as a preliminary issue, the action should be included in the Brussels I regime. ${ }^{20}$

Marc Rich clarifies that besides arbitration proceedings, any court proceedings in which the subject matter is arbitration should be excluded from the scope of the Brussels I regime. A decision should be made according to the main subject matter of the proceedings. If any incidental question or preliminary issue may be included in the Brussels I regime, it would not substantively change the fact that the whole proceedings are out of the scope of the Brussels I regime. Marc Rich refuses to split the proceedings and treat incidental questions and primary questions separately.

Marc Rich leaves open two important questions. The first is how to handle the validity and interpretation of arbitration agreements as a stand-alone dispute. The second is how to handle interim or protective measures that may be provided to support arbitration.

\section{II.3. Van Uden Maritime BV v Deco-Line}

The status of arbitration in the Brussels I Regulation is addressed again in Van Uden Maritime $B V \vee$ Deco-Line. ${ }^{21}$ In this case, one of the parties commenced arbitration proceedings pursuant to the arbitration agreement in their contract and applied at the same time to the Dutch courts for interim relief in the form of an order that the defendant pay the debt owed. The question was whether the Dutch court could exercise jurisdiction over the interim relief application under the Brussels I Regulation. It again depends on the scope of the Brussels I Regulation. Where the parties have concluded a valid arbitration agreement, are any court proceedings in relation to the parties' relationship arbitration-related and, therefore, excluded from the Brussels I Regulation? A broad

17 Schlosser, supra nt 9, para 61.

$18 I d$, para 18.

19 Id, para 29: 'the exclusion provided for therein extends to litigation pending before a national court concerning the appointment of an arbitrator, even if the existence or validity of an arbitration agreement is a preliminary issue in that litigation'.

20 Hess, B, Pfeiffer, T and Schlosser, P, Report on the Application of Regulation Brussels I in the Member States (Study JLS/C4/2005/03)

at $<$ ec.europa.eu/civiljustice/news/docs/study_application_brussels_1_en.pdf> (accessed 10 April 2015), para 107 (Heidelberg Report).

21 CJEU, Case C-391/95, Van Uden Maritime BV v Deco-Line [1998] ECR I-7091 (Van Uden); Rodger, BJ, "Interim Relief in Support of Foreign Litigation", 18 Civil Justice Quarterly (1999) 199; Hartley, TC, "Interim Measures under the Brussels Jurisdiction and Judgments Convention", 24 European Law Review (1999) 674. 
interpretation again supports that the exclusion should be extended to all proceedings relating to the parties' relationship, including interim measures. ${ }^{22}$ This is because the interim measures sought are 'intrinsically bound up with the subject-matter of an arbitration procedure' and should be regarded as ancillary to the arbitration procedure. ${ }^{23}$ A contrary argument is that the subject matter of the interim proceedings is not arbitration, but performance of a contractual obligation. ${ }^{24}$ The CJEU decided that the interim relief proceedings were commenced alongside the main court proceedings. The court that is seized under Article 24 of the Brussels Convention to issue an interim relief should have jurisdiction under the Convention regardless of existing proceedings in another Member State. This means the interim proceedings are independent from and parallel to the main proceedings. ${ }^{25}$ The CJEU thus suggested that interim proceedings are not court proceedings ancillary to arbitration, because they are ordered alongside arbitration procedures as additional support measures. ${ }^{26}$ Although Van Uden did not address the first gap left by Marc Rich, it answered the second question that the nature of interim or protective measures should be determined according to the substantive right they aim to enforce, instead of the proceedings that they could act to support. Interim proceedings in support of arbitration proceedings may still fall within the scope of the Brussels I Regulation.

\section{II.4. Allianz SpAv West Tankers (Front Comor)}

Ten years after Van Uden, a conflicting and controversial ruling on the relationship between arbitration and the Brussels I Regulation was delivered by the CJEU in Front Comor, ${ }^{27}$ where the claimant applied for an anti-suit injunction in an English court restraining the defendant from suing in Italy in an alleged breach of an arbitration agreement which required the parties to submit disputes to arbitration in London. If Marc Rich is applied, the Brussels I Regulation does not cover court proceedings the subject matter of which is arbitration. Proceedings to issue an anti-suit injunction to support arbitration based on the decision that an arbitration agreement is valid should be proceedings in which the subject matter is arbitration. ${ }^{28}$ If applying the ruling in Van Uden, the nature of the interim proceedings should depend on 'the nature of the right that they serve to protect' ${ }^{29}$ The anti-suit injunction aims to protect the right of the parties to bring disputes to arbitration. Therefore, pursuant to Van Uden, the proceedings to issue anti-suit injunction should be proceedings relating to arbitration and be excluded from the scope of the Brussels I Regulation.

The CJEU, however, ruled that an anti-suit injunction granted against another Member State's proceedings in favour of arbitration is within the scope of the Brussels I Regulation. The decision does not carefully address case precedents and legal principles within the Brussels I Regulation. After a very brief note that Marc Rich and Van Uden may lead to a conclusion to exclude the anti-suit injunction in support of arbitration from the scope of the Brussels I Regulation, the CJEU focuses on the policy consideration of

\footnotetext{
22 This broad interpretation was provided by the German and UK Governments: Van Uden, para 26.

23 Van Uden, para 26.

24 Van Uden, para 27.

25 Van Uden, paras 28 and 29.

26 Van Uden, paras 33-34.

27 CJEU, Case C-185/07, Allianz Spa v West Tankers, [2009] ECR I-663 (Front Comor).

28 United Kingdom House of Lords, West Tankers Inc $v$ RAS SpA and others [2007] UKHL 4, para 13.

29 Van Uden, para 33.
} 
preventing the use of anti-suit injunction among Member States. ${ }^{30}$ The CJEU departed from the 'subject matter' test used in both Marc Rich and Van Uden, and adopted a new test based on the 'effect' on the Community.

The Front Comor decision, as a primarily policy-based attack on the use of the anti-suit injunction as a tool in the internal market, does not provide a clear answer to the relationship between arbitration and the Brussels I Regulation. In particular, it should not be interpreted in a way suggesting that the validity of an arbitration clause, standing alone, is included in the Brussels I Regulation. It is doubtful whether, without the involvement of an anti-suit injunction or other measures that arguably infringe comity and mutual trust of the Brussels I regime, the same decision will be made with the effect of including decisions on arbitration agreements within the scope of the Brussels I Regulation.

\section{II.5. Conclusion}

No systematic and consistent guidance is provided by the CJEU in addressing the relationship between arbitration and the Brussels I Regulation. Pursuant to the previous case authorities, the CJEU provides four suggestions: (1) the Brussels I Regulation does not apply to arbitration proceedings; (2) the Brussels I Regulation does not apply to the court proceedings, the subject matter of which is arbitration; (3) the subject matter and the nature of the court proceedings depend on the nature of the right they seek to protect; (4) exception is given to anti-suit injunctions supporting arbitration, which, for policy reasons, is within the scheme of the Brussels I Regulation.

\section{Brussels I Recast}

\section{III.1. The Recasting Process and Reform Proposal}

The recasting process began with the Heidelberg study, which was completed in 2005. The responses to this study were used as the basis for the Heidelberg Report. The Heidelberg Report advocated wide-ranging reform of the Regulation's relationship with arbitration. ${ }^{31}$ The European Commission, generally based on the Heidelberg Report, published a Report ${ }^{32}$ and Green Paper, ${ }^{33}$ providing a few proposals for reform. Member States also suggested alternate options in their responses to the Green Paper. ${ }^{34}$ In general, six alternative proposals were considered in the recasting process.

30 Front Comor, paras 23-31. For more discussion on the three cases, see Tang, ZS Jurisdiction and Arbitration Agreements in International Commerce (Routledge, London, 2014), Ch 7.5.

31 Heidelberg Report, supra nt 20, para 122.

32 European Commission, Report from the Commission to the European Parliament, the Council and the European Economic and Social Committee on the application of Council Regulation (EC) No 44/2001 on jurisdiction and the recognition and enforcement of judgments in civil and commercial matters, 21 April 2009, COM(2009) 174 final (Commission Report), 7.

33 European Commission, Green paper on the review of Council Regulation (EC) No 44/2001 on jurisdiction and the recognition and enforcement of judgments in civil and commercial matters, COM (2009) 175 final, 6 (Commission Green Paper).

34 See eg., the responses to the Commission Green Paper: UK Ministry of Justice, Review of the Brussels I Regulation (EC 44/2001): Comments from the United Kingdom, 3 September 2009, 7 (UK Green Paper Response); Hungary, Hungarian Response to the Commission's Green Paper on the Review of Council Regulation (EC) No 44/2001 on the Jurisdiction and the Recognition and Enforcement of Judgments in Civil and Commercial Matters, COM(2009) 175, 8, Slovenia, Odgovori RS na vprašanja Zelene knjige o izvajanju Uredbe 
The first proposal is simple deletion of the arbitration exclusion, ${ }^{35}$ thereby bringing all court proceedings related to arbitration within the scope of the Brussels I regime, including the proceedings deciding on the validity of an arbitration agreement, appointing an arbitrator, and issuing other ancillary measures. This would likely result in an inappropriate regime: a square peg for a round hole. ${ }^{36}$ It is inappropriate to allow any Member State to interfere with foreign arbitration proceedings or to grant ancillary measures in relation to foreign arbitration. Furthermore, when the parties choose arbitration they have the intention to avoid the ordinary jurisdiction rules of the Brussels I regime and to be subject to a chosen, neutral forum. Some jurisdiction rules of the Brussels I regime would be inappropriate to support arbitration or to address parties' needs. For example, granting general jurisdiction to the defendant's domicile makes little practical sense in arbitration, where the parties tend to avoid each other's places of business in favour of a neutral forum. ${ }^{37}$ The simple deletion of the arbitration exclusion could result in parties being able - and in some circumstances, forced ${ }^{38}$ - to bring actions relating to arbitration in a manifestly inappropriate forum. Perhaps for this reason, the simple deletion of the arbitration exclusion without insertion of bespoke rules has never, to the authors' knowledge, been seriously proposed as an avenue for reform.

The second approach is the 'partial deletion' of the arbitration exclusion. ${ }^{39}$ The Heidelberg Report suggested deletion of the arbitration exclusion at Article 1(2)(d), ${ }^{40}$ supplemented by a number of bespoke rules on the interface between the Brussels I regime and arbitration, including giving exclusive jurisdiction in ancillary proceedings to the courts at the place of the arbitration, ${ }^{41}$ adding a new lis pendens rule requiring a mandatory stay of proceedings where the existence of an arbitration agreement is alleged and a court at the designated place of arbitration has been seized for declaratory relief, ${ }^{42}$

Sveta ES, št. 44/2001 o pristojnosti in priznavanju ter izvrševanju sodb v civilnih in gospodarskih zadevah, dokument št. COM (2009) $175 z$ dne 21.4.2009, 10-11 (translation with the assistance of Miss Janja Čevriz); Permanent Representation of the Republic of Poland at the European Union, Odpowiedzi na Pytania Zawarte w Zielonej Księdze w Sprawie Przeglądu Rozporządzenia Rady (WE) nr 44/2001 w Sprawie Jurysdykcji $i$ Uznawania Orzeczén Sadowych Oraz ich Wykonywania w Sprawach Cywilnych i Handlowych (COM(2009)175, 28 July 2009, 8-9) (translation with the assistance of Miss Marysia Łabno); La Delegation Français, Réponses des Autorités françaises au Livre vert relatif à la révision du règlement (CE) $n^{\circ} 44 / 2001$ du Conseil concernant la compétence judicaire, la reconnaissance et l'exécution des décisions en matière civile et commercial, 23) (translation with the assistance of Mlle Évodie Fleury); Bundesministeriums des Justiz, Grünbuch Überprüfung der Verordnung (EG) Nr 44/2001 des Rates über die gerichtliche Zuständigkeit und die Anerkennung und Vollstreckungvon Entscheidungen in Zivil- und Handelssachen (KOM [2009] 175 endgültig) vorgelegt von der Kommission am 21 April 2009 (translation with the assistance of Frau Eva Loef); all responses are at <ec.europa.eu/justice/newsroom/civil/opinion/090630_en.htm> (accessed 9 May 2015).

35 Heidelberg Report, supra nt 20, paras 122-124; Radicati di Brozolo, LG, "Arbitration and the Draft Revised Brussels I Regulation: Seeds of Home Country Control and of Harmonisation?”, 7(3) Journal of Private International Law (2011) 423, 429.

36 Ibid.

37 Bühring-Uhle, C, Arbitration and Mediation in International Business (Kluwer, Alphen aan den Rijn, 1996), 135-143.

38 If the arbitration agreement did not specify a place for performance, the only option for a Court to establish jurisdiction over the arbitration agreement would be to rely on the domicile rule.

39 The Commission Report, and the Commission Green Paper advocated partial deletion of the exclusion in this fashion; the Heidelberg Report had previously suggested deletion with the insertion of bespoke rules.

40 Heidelberg Report, supra nt 20, para 131.

41 Id, para 132.

$42 \quad I d$, para 134. 
and inserting a recital defining the place of arbitration. ${ }^{43}$ The simple but appealing central argument in favour of this approach is that it could resolve parallel proceedings between courts and arbitration and could prevent irreconcilable judgments on ancillary proceedings between Member States. ${ }^{44}$ These proposals, however, are subject to strong criticism. ${ }^{45}$ The criticism generally suggests that this proposal would have resulted in a backward step for pro-arbitration EU Member States, undermined arbitral competencecompetence, and interfered with the New York Convention regime. For example, a Member State with particularly strict requirements for the validity of an arbitration agreement could force other Member States to apply those restrictions indirectly, by issuing a Brussels I Regulation judgment on the validity of the arbitration agreement or setting aside an award. This would be an anathema to a pro-arbitration country such as France, which does not currently recognise the judicial annulment of awards in another country under any circumstances. ${ }^{46}$ Regardless of its merits, the possibility of the partial abolition of the exclusion was seriously considered in the recasting process.

The third approach is a return to a so-called 'true' arbitration exclusion. This would mean maintaining the exclusion, but wording it more broadly, to the extent that it would revive the anti-suit injunction and render the Front Comor decision irrelevant. ${ }^{47}$ The exact proposal from the UK fell into three parts. First, it would reword the arbitration exclusion in Article 1(2)(d), making its scope absolutely clear. The reworded exclusion would read

arbitration, and in particular an action in respect of which the parties have made an arbitration agreement within the meaning of Article II of the New York Convention; an action or judgment on the validity, effect or scope of such an agreement; and ancillary proceedings in relation to such an agreement or any aspect of the arbitral process. ${ }^{48}$

It would then include a recital that a court may refuse recognition and enforcement of a judgment irreconcilable with an arbitration agreement. ${ }^{49}$ Finally, it would insert a

43 Id, para 136. See also van Houtte, H, "Why Not Include Arbitration in the Brussels Jurisdiction Regulation?", 21(4) Arbitration International (2005) 509, 516-520. See also the independent scholarship of the authors of the Heidelberg Report: Schlosser PF, "Europe - Is It Time to Reconsider the Arbitration Exception from the Brussels Regulation?", 12(4) International Arbitration Law Review (2009) 45; Hess, B, "Improving the Interface Between Arbitration and European Procedural Law - the Heidelberg Report on the EU Commission's Green Paper on the Reform of Regulation Brussels I", 1 Les Cahiers de l'Arbitrage/Paris Journal of International Arbitration (2010) 17; Hess, B, Pfeiffer, T and Schlosser, PF, "The Findings and Proposals of the Heidelberg Report - a Reply to the ICC French Working Group", 1 Transnational Dispute Management (March 2009) at <transnational-disputemanagement.com/article.asp?key=1424> (accessed 4 May 2015).

44 Heidelberg Report, supra nt 20, paras 115-129; van Houtte, supra nt 43, 512-520.

45 See Pinsolle, P, "The Proposed Reform of Regulation 44/2001: A Poison Pill for Arbitration in the EU?", 12(4) International Arbitration Law Review (2009) 62, 62-65; Pullen, A, "The future of International Arbitration in Europe: West Tankers and the EU Green Paper",12(4) International Arbitration Law Review (2009) 56; The Arbitration Committee of the IBA, "IBA Submission to the European Commission on Regulation (EC) No. 44/2001", 10 Business Law International (2009) 302; UK Green Paper Response, supra nt 34, 7; Radicati di Brozolo, supra nt 35, 434.

46 See, eg., Cour de Cassation, Première Chambre Civile, France No 42, PT Putrabali Adyamulia (Indonesia) $v$ Rena Holding, et al, 29 June 2007, XXXII Yearbook of Commercial Arbitration (2007) 299 (PT Putrabali).

47 UK Green Paper Response, supra nt 34, 7.

48 Id, 7-8.

49 Id, 8: 
provision stating: 'Nothing in this Regulation affects the application of the New York Convention'. ${ }^{50}$ This approach also found support in the European Parliament Report, at least insofar as it would broaden the understanding of the arbitration exclusion. ${ }^{51}$

Fourth, the European Commission in its later Proposal suggested a lis pendens mandatory stay rule. ${ }^{52}$ It requires the court of a Member State to stay jurisdiction where either the courts at the seat of arbitration or the arbitral tribunal itself had been seized. Parties would not be obliged to go to court before commencing arbitration in order to receive the lis pendens protection of the Brussels I Regulation: an onerous requirement which would have delayed the proceedings and added expense in cases where, for example, institutional rules would remove any need for court involvement. This proposal found support in the writings of several commentators. It would arguably solve the most significant problem with the Brussels I Regulation's relationship with arbitration parallel proceedings - without being overly intrusive into the domestic arbitration law of the Member States. ${ }^{53}$ The obvious criticism of this proposal is that it would allow the badfaith tactical litigant to delay or 'torpedo' potential court proceedings by attempting to begin vexatious arbitration proceedings where no arbitration agreement had been

50 Ibid.
In order to ensure that all aspects of arbitration are kept outside the scope of this Regulation, and to safeguard the full application and operation between Member States of the United Nations Convention on the Recognition and Enforcement of Foreign Arbitral Awards of 1958 ('the New York Convention'), unaffected by this Regulation, this Regulation should not apply to actions in respect of matters governed by an arbitration agreement under Article II of the New York Convention; actions or judgments on the existence, validity, effect or scope of such an arbitration agreement; or ancillary proceedings relating to such an arbitration agreement or any aspect of the arbitral process; and a judgment should not be recognisable under this Regulation in so far as it is irreconcilable with such an arbitration agreement.

51 European Parliament, Report on the implementation and review of Council Regulation (EC) 44/2001 on jurisdiction and recognition and enforcement of judgments in civil and commercial matters, Session Document A7-0219/2010 (2009/2140(INI)), 5 (Parliament Report).

52 Article 29(4), European Commission, Proposal for a Regulation of the European Parliament and of the Council on jurisdiction and the recognition and enforcement of judgments in civil and commercial matters (Recast), 14 December 2010, COM(2010) 748 final, 36 (Commission Proposal):

Where the agreed or designated seat of an arbitration is in a Member State, the courts of another Member State whose jurisdiction is contested on the basis of an arbitration agreement shall stay proceedings once the courts of the Member State where the seat of the arbitration is located or the arbitral tribunal have been seised of proceedings to determine, as their main object or as an incidental question, the existence, validity or effects of that arbitration agreement.

This paragraph does not prevent the court whose jurisdiction is contested from declining jurisdiction in the situation referred to above if its national law so prescribes.

Where the existence, validity or effects of the arbitration agreement are established, the court seised shall decline jurisdiction.

This paragraph does not apply in disputes concerning matters referred to in Sections 3, 4, and 5 of Chapter II.

Article 33(3), Commission Proposal:

For the purposes of this Section, an arbitral tribunal is deemed to be seised when a party has nominated an arbitrator or when a party has requested the support of an institution, authority or a court for the tribunal's constitution.

53 Radicati di Brozolo, supra nt 35, 436-440; Benedettelli, MV, “'Communitarization' of International Arbitration: A New Spectre Haunting Europe?”, 27(4) Arbitration International (2011) 582; Harris, J, "The Commission's Proposal for reform of the Judgments Regulation", 26(7) Butterworths Journal of International Banking and Financial Law (2011) 389. 
concluded. However, the proposal is laudable for furthering the aim of eradicating parallel proceedings whilst having less pervasive effects than the partial deletion of the arbitration exclusion and requiring a less radical rethink of the Regulation's relationship with arbitration or the scope of the arbitration exclusion.

The fifth possible approach is the ad hoc harmonisation of arbitration law through various routes. One such proposal is to harmonise the law through European legislation. ${ }^{54}$ This would improve the interface between the Brussels I regime and arbitration by ensuring a uniform standard for the validity of arbitration agreements, setaside standards, and so on, with a supranational court system to ensure consistent interpretation and application. This proposal could therefore feasibly solve, or at least drastically reduce the effect of, the problems caused by the exclusion of arbitration from the Brussels I regime. A doctrinally similar suggestion ${ }^{55}$ is that EU Member States could conclude a protocol to the New York Convention to govern the validity of arbitration agreements. ${ }^{56}$ A protocol is seen as the most suitable instrument because it is unlikely that the New York Convention could be amended, given that it is so widely in force. ${ }^{57}$ It has also been suggested that such a protocol could provide for the possibility of appeal to the CJEU, again, to ensure its uniform interpretation across the Member States. ${ }^{58}$ Both suggestions can be criticised for the risk that they will promote a less arbitration-friendly law than that which would otherwise be applied in the states in which arbitration is popularly conducted, stifling both intra-European competition and competition amongst European Member States and the rest of the world for arbitration business. ${ }^{59}$ The former proposal also raises troubling questions of legislative competence.

Finally, there were those who argued that the problems discussed in the last part were not sufficiently serious to warrant reform and that the best option was to leave things as they were. ${ }^{60}$ However, this 'if it's not broken, don't try to fix it' approach became untenable for political reasons. The Commission was determined to come up with some kind of reform. ${ }^{61}$ For this reason, those who originally favoured that approach tended to begin to favour more minimalist reforms, such as the Commission Proposal of nothing but a lis pendens rule.

\section{III.2. Brussels I Recast}

The previous section gave an overview of the debate and possible approaches for the Recast to take towards arbitration. The Recast was passed in late 2012 and came into effect in January 2015. ${ }^{62}$ The approach taken was to retain the exclusion of arbitration in Article $1(2)(d)$ with virtually no changes to the enacting provisions of the Recast itself. The main relevant change is the insertion of Recital 12, which contains four paragraphs clarifying the Recast's relationship with arbitration. The second is the insertion of a new Article 73(2), which expressly provides for the supremacy of the New York Convention

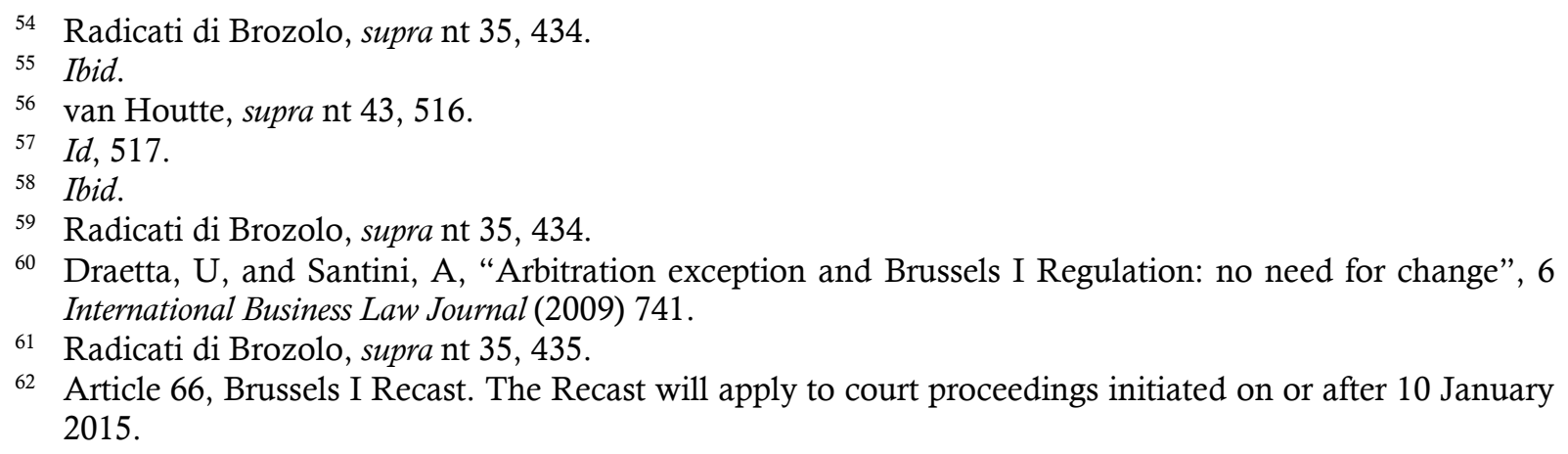

61 Radicati di Brozolo, supra nt 35, 435.

62 Article 66, Brussels I Recast. The Recast will apply to court proceedings initiated on or after 10 January 2015. 
over the Recast. This section shall first consider why the changes have been introduced by way of a recital rather than enacting provisions and the effect this might have on the proper interpretation of the Recast. It shall then examine the changes introduced by each paragraph of Recital 12 and in Article 73(2) in turn.

\section{III.2.1. Choice of a Recital}

Most commentaries on the Brussels I Recast and its relationship with arbitration do not consider the legal nature of a recital, simply assuming that Recital 12 is operative in its entirety. ${ }^{63}$ It has also been suggested that Article 288 TFEU $^{64}$ renders an EU regulation in its entirety, including its preamble where relevant, binding on Member States. ${ }^{65}$ This slightly oversimplifies what is admittedly a complex matter and could bear upon the proper interpretation of Recital 12.

According to the EU institutions' drafting guide, recitals are included to set out reasons for the enacting provisions, without reproducing them or containing normative provisions. ${ }^{66}$ This is in line with the academic view that recitals should lend context to the enacting provisions. ${ }^{67}$

Recitals can therefore help in the judicial interpretation of unclear enacting provisions. ${ }^{68}$ The CJEU has developed a number of principles regarding the effect of recitals to EU legislation. ${ }^{69}$ It has been held that the language of a recital cannot limit a right contained in the enacting provisions, ${ }^{70}$ but equally, neither can it confer a right clearly not granted nor denied by the operative provisions. ${ }^{71}$ The Court is, however, ready to use recitals to interpret the scope of enacting provisions although this is unclear from

63 See Erk, N, Parallel Proceedings in International Arbitration: A comparative European Perspective (Kluwer Law International, Alphen aan den Rijn, 2014), 66-68; Hauberg-Wilhelmsen, L, "The Recast Brussels I Regulation and Arbitration: Revisited or Revised?", 30(1) Arbitration International (2014) 169; Camilleri, S-P, "Recital 12 of the recast Regulation: a New Hope?", 62(4) International and Comparative Law Quarterly (2013) 899.

64 Article 288 (ex Article 249 TEC), Consolidated version of the Treaty on the Functioning of the European Union (2012) OJ C326/01 (TFEU): provides in relevant part 'A regulation shall have general application. It shall be binding in its entirety and directly applicable in all Member States'.

65 Carducci, G, "The New EU Regulation 1215/2012 of 12 December 2012 on Jurisdiction and International Arbitration: with Notes on Parallel Arbitration, Court Proceedings and the EU Commission's Proposal" 29(3) Arbitration International (2013) 467, 469.

66 See European Union, Legal Services of the European Parliament, Council and Commission, Joint Practical Guide of the European Parliament, the Council and the Commission for persons involved in the drafting of European Union Legislation (2nd edn, 2013), at <eur-lex.europa.eu/content/pdf/techleg/joint-practicalguide-2013-en.pdf> (accessed 28 April 2015), 19: 'The purpose of the recitals is to set out concise reasons for the chief provisions of the enacting terms, without reproducing or paraphrasing them. They shall not contain normative provisions or political exhortations'.

67 Editorial, "Contextual legislative elements as fomites", 25(3) Statute Law Review (2004) iii.

68 See, eg., English and Wales Court of Appeal, Oliver Ashworth (Holdings) Ltd v Ballard (Kent) Ltd [2000] Ch 12, 37-39; International Court of Justice (ICJ), Case concerning Rights of Nationals of the United States of America in Morocco (France v United States of America), ICJ Reports 176, 27 August 1952, 196.

69 This is summarised neatly in Klimas, T and Vaiciukaite, J, "The Law of Recitals in European Community Legislation", 15 ILSA Journal International \& Comparative Law (2008) 61, 83-87.

70 CJEU, Case C-162/97, Criminal proceedings against Gunnar Nilsson, Per Olov Hagelgren and Solweig Arrborn, [1998] ECR I-07477, para 54: '...the preamble to a Community act has no binding legal force and cannot be relied on as a ground for derogating from the actual provisions of the act in question'.

71 CJEU, Case C-308/97, Giuseppe Manfredi v Regione Puglia, [1998] ECR I-07685, para 30. 
the enacting provisions themselves. ${ }^{72}$ This is unsurprising, given the CJEU's usual purposive approach to statutory interpretation.

Recital 12 will therefore be capable of giving context to a provision whose meaning or scope is unclear from its wording, such as the arbitration exclusion. It will not, however, be able to grant any sort of right that is not contained in the enacting provisions, nor will it be able to restrict access to any right contained in such a provision. These principles help give a fuller understanding to the implications of the Recital.

\section{III.2.2. Recital 12, paragraph 1}

This Regulation should not apply to arbitration. Nothing in this Regulation should prevent the courts of a Member State, when seised of an action in a matter in respect of which the parties have entered into an arbitration agreement, from referring the parties to arbitration, from staying or dismissing the proceedings, or from examining whether the arbitration agreement is null and void, inoperative or incapable of being performed, in accordance with their national law.

The first sentence of this paragraph merely restates the arbitration exclusion without adding any wider context. The second sentence essentially enshrines the Marc Rich principle. The new recital, however, makes one potentially important change to the previous understanding of the exclusion. Previously, the applicability of the Brussels I Regulation was decided using a subject matter test. ${ }^{73}$ The court's jurisdiction was contingent on the very fact that those proceedings were ancillary to arbitration. In the Front Comor case, the main subject matter before the court revolved around merits. Consequently, those proceedings, in their entirety - including incidental questions as to the validity of an arbitration agreement - would fall within the scope of the Brussels I Regulation. This would mean that a court second-seized of an action on the merits could be bound by the decision of the court first-seized on the incidental matter of the applicability of an arbitration agreement.

The rule in the first paragraph of Recital 12 would mean that a court second-seized of a merits action could immediately stay the merits action and refer the parties to arbitration, no matter what has been decided about the arbitration agreement as a preliminary matter in foreign merits proceedings. The first paragraph of Recital 12 therefore tweaks the CJEU's jurisprudence in a subtle, arbitration-friendly fashion, allowing arbitration agreements to function more effectively. The Recital in this way provides guidance on the interpretation of the scope of the enacting provision, Article $1(2)(d)$.

Finally, it is worth noting that paragraph 1 of Recital 12 mentions that courts may assess some ancillary issues 'with their national law'. The reference to national law is at odds with the New York Convention's provisions, which imply that validity of the arbitration agreement should be judged under to the law chosen by the parties, failing which the law of the juridical seat of the arbitration, failing which the law determined by the international private law rules. ${ }^{74}$ This may mean that, in the desire not to interfere

72 CJEU, Case C-288/97, Consorzio fra i Caseifici dell'Altopiano di Asiago v Regione Veneto, [1999] ECR I02575, para 23.

73 Marc Rich, para 26.

74 See Articles II and V(1)(a), New York Convention. 
with the operation of the New York Convention, the European legislators have, in fact, impliedly created a new choice of law rule entirely at odds with it.

\section{III.2.3. Recital 12, paragraph 2}

A ruling given by a court of a Member State as to whether or not an arbitration agreement is null and void, inoperative or incapable of being performed should not be subject to the rules of recognition and enforcement laid down in this Regulation, regardless of whether the court decided on this as a principal issue or as an incidental question.

This paragraph overturns the rule in Front Comor that judgments on the validity of an arbitration agreement will be subject to the Brussels I Regulation where the main subject matter of the proceedings is also covered by the Regulation. Thus in a scenario where a court is seized on the merits of a dispute, purportedly subject to an arbitration agreement, the judgment of that court as to the validity of the arbitration agreement will no longer fall within the scope of the Brussels I Recast and will never be capable of directly binding another Member State's court. This is a departure from the predominant post-Front Comor interpretation of the arbitration exclusion before the Brussels I Recast. ${ }^{75}$ The recital therefore clarifies the intended scope of the exclusion.

\section{III.2.4. Recital 12, paragraph 3}

On the other hand, where a court of a Member State, exercising jurisdiction under this Regulation or under national law, has determined that an arbitration agreement is null and void, inoperative or incapable of being performed, this should not preclude that court's judgment on the substance of the matter from being recognised or, as the case may be, enforced in accordance with this Regulation. This should be without prejudice to the competence of the courts of the Member States to decide on the recognition and enforcement of arbitral awards in accordance with the Convention on the Recognition and Enforcement of Foreign Arbitral Awards, done at New York on 10 June 1958 ('the 1958 New York Convention'), which takes precedence over this Regulation.

The first sentence of this paragraph provides that when a court renders a judgment on the merits after holding an arbitration agreement invalid or inapplicable, its judgment on the merits (but not the arbitration agreement, according to paragraph 2 , above) will be enforceable under the Regulation.

The second sentence attempts to address the conflict of obligations that arises when a court has on the one hand the duty to enforce a judgment under the Regulation and, on the other hand, the duty to enforce an arbitral award or agreement in the same dispute under the New York Convention. ${ }^{76}$ Recital 12 states that the duty to enforce such judgments will be 'without prejudice to the competence of the court' to decide on its New York Convention obligation to enforce arbitral awards. It has been suggested that this sentence means that a court faced with a conflicting judgment and arbitral award in the same dispute can recognise and/or enforce the arbitral award in preference to the

75 Hauberg-Wilhelmsen, supra nt 63, 181-182.

76 Article III, New York Convention. 
judgment. ${ }^{77}$ This is not consistent with a plain-text reading of the Brussels I Recast. The existence of a contradictory arbitral award is clearly not a ground for refusing recognition and enforcement of a judgment under the Recast. ${ }^{78}$ Therefore a court faced with a conflicting judgment and arbitral award would be considered bound to recognise and/or enforce both the judgment under the Brussels I regime and the arbitral award under the New York Convention, just as it currently would be.

Two main arguments support this view. The first is the fact that the sentence is part of a recital and, therefore, as set out above, is neither capable of creating rights not contained in the enacting provisions, nor of causing derogation from any right expressly contained in the enacting provisions. The enacting provisions of the Brussels I Recast give a litigant the right to have Regulation judgments recognized and enforced in the courts of other Member States. ${ }^{79}$ The provisions also contain an exhaustive list of grounds for refusal of recognition and enforcement, in which the existence of a contradictory arbitral award is not included. ${ }^{80}$ Recital 12 , by its legal nature, is not capable of changing this.

The second argument is that, although the New York Convention is given precedence over the Regulation in the enacting provisions, ${ }^{81}$ the New York Convention does not in any way provide rules for the recognition and enforcement of judgments, only of arbitral awards. Its precedence therefore means little, because it does not contain conflicting rules. That precedence has a much more obvious application, for example, in terms of the effect of an arbitration agreement on court jurisdiction. ${ }^{82}$ For these reasons, the suggestion that Recital 12, paragraph 3 allows the refusal of enforcement of a Brussels I Regulation judgment on the basis of the existence of a contradictory arbitral award cannot be supported.

The paragraph could perhaps be argued to justify a refusal to enforce a judgment on the ground of the public policy exception. ${ }^{83}$ This is no different to the situation before the conclusion of the Brussels I Recast, although Recital 12 may add force to the argument that enforcement of arbitral awards is an element of international public policy. ${ }^{84}$ Then again, public policy in the EU is to be construed narrowly ${ }^{85}$ so this interpretation should not be readily inferred.

There is even less clarity in the Brussels I Recast and Recital 12, paragraph 3 regarding the approach to the recognition and enforcement of a judgment rendered in spite of what the enforcing court considers a valid agreement to arbitrate. The proper approach to this issue is no clearer under the Brussels I Recast than it was under the Brussels I Regulation, because the first sentence of Recital 12, paragraph 3 states that, where another court has rendered a judgment in spite of an arbitration agreement, its judgment on the merits is enforceable under the Recast. The second sentence qualifies this rule as not prejudicing

77 Erk, supra nt 63, 67.

78 Article 45, Brussels I Recast contains the list of grounds for refusal of recognition and enforcement of judgments under the Recast.

79 Articles 36 and 39, Brussels I Recast.

80 Article 45, Brussels I Recast.

81 Article 73(2), Brussels I Recast.

82 Because the New York Convention contains a rule on court jurisdiction in Article II, this rule takes precedence over the rules of the Brussels I Regulation for the purpose of establishing jurisdiction over a dispute in respect of which the parties have made an arbitration agreement, as it always has done.

83 Article 45(1)(a), Brussels I Recast.

84 Camilleri, supra nt 63, 915.

85 CJEU, Case C-7/98, Dieter Krombach v André Bamberski, [2000] ECR I-01935; CJEU, Case C-38/98, Régie nationale des usines Renault SA v Maxicar SpA and Orazio Formento, [2000] ECR I-02973. 
the competence of courts to decide on the enforcement of arbitration awards under the New York Convention. This takes precedence over the Recast. Article 73(2), discussed below, states expressly in the enacting provisions that the New York Convention should take precedence over the Recast. But, as mentioned above, the New York Convention also provides a jurisdictional rule that a court '...seized of an action in a matter in respect of which the parties have made an agreement [to arbitrate] shall, at the request of one of the parties, refer the parties to arbitration... ${ }^{86}$

Recital 12, paragraph 3 does not address the correct approach for a court to take in the situation where it is asked to enforce a judgment rendered in spite of what it views to be a valid arbitration agreement (not award) and is therefore incapable of providing the correct approach to this situation. The first sentence of paragraph 3 states that the court judgment on the merits should be enforceable. The second sentence qualifies this as not affecting the enforcement of arbitral awards under the New York Convention, but makes no mention of arbitration agreements. The court will find itself facing conflicting obligations under the Brussels I Recast, as interpreted according to Recital 12, paragraph 3 of the Brussels I Recast and Article II of the New York Convention, if it considers the enforcement of a judgment on merits to constitute 'a matter in respect of which' the parties have made an arbitration agreement.

It seems in all the circumstances that the difficulties posed by a judgment rendered in spite of an arbitration agreement or award will therefore continue to trouble courts under the Brussels I Recast regime, irrespective of the words of paragraph 3.

\section{III.2.5. Recital 12, paragraph 4}

This Regulation should not apply to any action or ancillary proceedings relating to, in particular, the establishment of an arbitral tribunal, the powers of arbitrators, the conduct of an arbitration procedure or any other aspects of such a procedure, nor to any action or judgment concerning the annulment, review, appeal, recognition or enforcement of an arbitral award.

This is simply a restatement of the meaning given to the arbitration exclusion in Marc Rich ${ }^{87}$ According to academic opinion, there is no indication that the exclusion has been strengthened in the fashion desired by the UK so as to reinstate the anti-suit injunction in such proceedings. ${ }^{88}$ That said, it should be noted that Advocate General Wathelet in his opinion in the Gazoprom case cites this paragraph in support of the contention that antisuit injunctions in support of arbitration will once again be permitted under the Brussels I Recast. ${ }^{89}$ It remains to be seen at the time of writing whether the CJEU will adopt this Opinion, but it is suggested that this is unlikely. Such a radical change to the prevailing understanding of the arbitration exclusion would surely have been made expressly, and the CJEU's principle-based reasoning in Front Comor is likely to be unaltered by the

86 Article II(3), New York Convention.

87 Marc Rich, paras 21 and 26.

88 Erk, supra nt 63, 68; Camilleri, supra nt 63, 904-908. Even Moses, who clearly supports the anti-suit injunction and raises the question of the reinstatement of the remedy via the complete exclusion of arbitration, concludes that this is an unlikely outcome. See Moses, M, "Arbitration/Litigation Interface: The European Debate" Loyola University Chicago School of Law Public Law \& Legal Theory Research Paper No 2014-5/6(2014), 45.

89 CJEU, Case C-536/13, Gazoprom OAO, Opinion of Advocate General Wathelet, 4 December 2014, para 136-137. 
addition of this vague paragraph that seems to do nothing more than restate the Marc Rich rule.

\section{III.2.6. Article 73 (2)}

This Regulation shall not affect the application of the 1958 New York Convention.

This provision makes clear what ought to have been the case under Article 71 of the Brussels I Regulation: ${ }^{90}$ that the New York Convention takes precedence over the Regulation. ${ }^{91}$ Although never tested before the CJEU, the alleged supremacy of the New York Convention would likely have been subject to the same narrow interpretation of Article 71, by which supremacy was given to the $\mathrm{CMR}^{92}$ in the TNT case. In that case, the CMR was held to have supremacy only insofar as it was consistent with the principles underlying the Brussels I Regulation. ${ }^{93}$

The express precedence provision in Article 73(2) could be interpreted to mean that the New York Convention takes precedence over the Brussels I Recast completely, not only insofar as it is consistent with the underlying goals of the Recast. This could possibly include giving precedence to the obligation to enforce an arbitral award over the obligation to enforce a Brussels I regime judgment on the same matter, as discussed above. This argument runs afoul of the analysis that there is no actual substantive conflict between the New York Convention and the Brussels I Recast. The New York Convention does not provide any rules concerning the enforcement of court judgments regarding matters in respect of which the parties have made an arbitration agreement. Nor does the Brussels I Recast contain provisions to deal with conflicts between a Regulation judgment and a contradictory arbitral award or an arbitration agreement, as the Hague Convention did in $1971 .{ }^{94}$

The New York Convention has, however, always been treated as supreme in respect of its rule regarding court jurisdiction where the parties to a dispute have concluded an arbitration agreement. ${ }^{95}$ Thus when the parties have concluded an arbitration agreement, a court will never have jurisdiction over the substance of the dispute, even if it otherwise would under the Brussels I regime.

A separate question is whether the jurisdiction provision of Article II(3) New York Convention could be used to justify a refusal to enforce a judgment rendered in spite of an arbitral agreement. This suggestion is weak, especially because the court asked for enforcement of a regime judgment in respect of a matter would be unlikely to view itself

90 Article 71(1), Brussels I Regulation provides: 'This Regulation shall not affect any conventions to which the Member States are parties and which in relation to particular matters, govern jurisdiction or the recognition or enforcement of judgments.'

91 Roodt, C, "Conflicts of Procedure between Courts and Arbitral Tribunals with Particular Reference to the Right of Access to Court", 19(2) African Journal of International and Comparative Law (2011) 236, 239; Pullen, supra nt 45.

92 United Nations, Geneva Convention on the Contract for the International Carriage of Goods by Road, (1956) 399 UNTS 189 (CMR). The official abbreviation 'CMR' comes from the French title of the Convention: Convention relative au contrat de transport international de marchandises par route.

93 CJEU, Case C-533/08, TNT Express Nederland BV v Axa Versicherung AG, [2010] ECR I-4107, para 51 (TNT): in which it was held that 'Article 71 of Regulation 44/2001 cannot have a purport that conflicts with the principles underlying the legislation of which it is part.'

94 Article 12, Convention on the recognition and enforcement of foreign judgements in civil and commercial matters, (1971) 1144 UNTS 249 (Hague Convention); Carducci, supra nt 65, 477.

95 Article II(3), New York Convention. 
as 'seised of' the matter which forms the substance of the judgment. Rather it is 'seised of' an action for the enforcement of a judgment, which forms a separate basis for founding jurisdiction under the Brussels I Regulation, distinct from the merits of the dispute.

Accordingly, it cannot not be argued that Article II(3) of the New York Convention justifies the refusal to recognise and enforce a Brussels I regime judgment rendered in spite of an arbitration agreement, even if the New York Convention takes absolute precedence over the Brussels I Recast.

In conclusion, therefore, it is difficult to see how the specific provision for the precedence of the New York Convention in the Brussels I Recast makes any difference to the general supremacy it had been granted under the Brussels I Regulation. ${ }^{96}$

\title{
III.2.7. Criticism of the Recast Approach
}

It is submitted that the Recast fails to make more than minute changes to the Brussels I Regulation's relationship with arbitration, despite the many problems that had been identified and the proposals made in an attempt to address these.

One might reasonably wonder why the proposals for reform were abandoned so quickly. The original Heidelberg Report and Commission proposals were obviously scaled back in the face of Member State opposition after the circulation of the Commission's Green Paper. The scaled-back proposal of a mandatory stay provision was rejected following strong opposition in Parliament. The Parliament Report states that

\begin{abstract}
it appears from the intense debate raised by the proposal to create an exclusive head of jurisdiction for court proceedings supporting arbitration in the civil courts of the Member States that the Member States have not reached a common position thereon and that it would be counterproductive, having regard to world competition in this area, to try to force their hand..$^{97}$
\end{abstract}

Anecdotal evidence, as well as the reference to competition for arbitration business, suggests that the UK and French representatives were the main obstacles to agreement. Upon the conclusion of the Recast, the Council's press release also raises other issues, such as the abolition of exequatur, and the need to address this as a priority. ${ }^{98}$ Perhaps reaching a compromise on wider reform of the Regulation's relationship with arbitration was simply viewed as an impediment that would delay the achievement of these more important goals.

The addition of Recital 12, as outlined above, has changed next to nothing and addressed none of the perceived problems at the interface between the Brussels I regime and arbitration. Of particular regret is the failure to restrict parallel proceedings. These had been identified as the most significant problem with the relationship between the Brussels I Regulation and arbitration. It was also clearly identified by the Commission as a priority for reform, given it was the focus of the scaled-back proposal following the Green Paper consultation.

96 Erk, supra nt 63, 67 nt 390.

97 Parliament Report, supra nt 33, 5.

98 Council of the European Union, Recast of the Brussels I regulation: towards easier and faster circulation of judgments in civil and commercial matters within the EU, 6 December 2012, 16599/12 PRESSE 483. 
Allowing parallel proceedings runs contrary to the principle of mutual trust between Member States of the European Union; it undermines the predictability of and certainty provided by the Brussels I regime, it is inconsistent with the Regime's approach to lis pendens in other matters, and it does not align with the principles enshrined in the Brussels I Recast's provisions regarding the choice of court agreements, which expressly promote party autonomy. ${ }^{99}$ This failing in particular, along with the general inertia of the reform process, is open to criticism. ${ }^{100}$

\section{Suggestions for Future Reform}

The confusion as to the meaning and extent of the arbitration exclusion, as well as the problems that have been identified at the interface between the Brussels I Regulation and arbitration, may recommend a radical new approach. This article will simply identify some crucial principles that should be borne in mind if the rule is subject to reform again in the future.

\section{IV.1. Mutual Trust}

'Mutual trust' between Member States has developed as a crucially important normative concept in the European law of jurisdiction. Mutual trust is mentioned in recitals as a foundational principle of the Brussels I Regulation and Recast. ${ }^{101}$ Mutual trust requires that courts of one Member State respect the right of the court of another Member State to determine its own jurisdiction and respect the result it reaches. The concept underlies the judgment in the Overseas Union case, ${ }^{102}$ although it is not expressly mentioned. It is also a central part of the ratio decidendi in the Front Comor, the Gasser case and many others. ${ }^{103}$ Mutual trust has also been argued to be a wide-ranging, long-standing tenet of European law, specifically visible in case law concerning fundamental freedoms. ${ }^{104}$

Mutual trust in this sense is clearly undermined by the exclusion of arbitration from the Brussels I Regulation. Member State courts are free to second-guess one another's decisions relating to arbitration, whether on the validity of an arbitration agreement or on the setting aside of an award. ${ }^{105}$ The decision in the Front Comor deprived the courts of Member States of the anti-suit injunction as a means of protecting arbitration

99 Recital 22, Article 31, Brussels I Recast; Dowers, NA and Holloway, D, "Brussels I Recast Passed", 16(2) International Arbitration Law Review (2013) N18, N20.

100 For more criticism, see Tang, supra nt 30, Ch 7, section 6.2 .

101 Recitals 3 and 16, Brussels I Regulation; Recital 26, Brussels I Recast.

102 CJEU, Case C-351/89, Overseas Union Insurance Ltd and others $v$ New Hampshire Insurance Company, [1991] ECR I-03317 (Overseas Union case).

103 Front Comor, para 30; CJEU, Case C-116/02, Erich Gasser GmbH v MISAT Srl, [2003] ECR I-14693, para 72 (Gasser). See also CJEU, Case C-139/10, Prism Investments BV v Jaap Anne van der Meer, in his capacity as receiver in the liquidation of Arilco Holland BV, [2011] ECR I-9511, paras 27-31; CJEU, Case C-619/10, Trade Agency Ltd v Seramico Investments Ltd, ECLI:EU:C:2012:531, 6 September 2012, paras 40-46; CJEU, Case C-456/11, Gothaer Allgemeine Versicherung AG v Samskip GmbH, ECLI:EU:C:2012:554, 15 November 2012, paras 28-29.

104 See Blobel, F, and Spath, P, "The Tale of Multilateral Trust and the European Law of Civil Procedure", 30(4) European Law Review (2005) 528, 533, nts 28 and 29. The authors argue that mutual trust is an important element in the decision of the landmark Cassis de Dijon case (CJEU, Case C120/78, Rewe-Zentrale AG v Bundesmonopolverwaltung für Branntwein, [1979] ECR I-00649).

105 The situation in the Front Comor clearly demonstrates the possibility for conflicting decisions on the validity of an arbitration agreement; for conflicts on the setting aside of an award, see Putrabali. 
proceedings, but without providing any trust-based alternative, such as a lis pendens rule. ${ }^{106}$

Rules such as a mandatory stay or a lis pendens rule in favour of the court at the seat of the arbitration or the arbitral tribunal could effectively resolve this situation with due respect for the importance of mutual trust. Furthermore, it would be consistent with the principle of mutual trust for Member State courts to respect one another's set-aside judgments.

This suggestion would not overly interfere with the New York Convention, because it exclusively concerns court proceedings related to arbitration rather than the jurisdiction of arbitral tribunals or the enforcement of arbitral awards themselves. ${ }^{107}$ It is therefore submitted that, properly drafted, there should be no reason for diffidence on the part of EU legislators in making such changes.

\section{IV.2. Legal Certainty and Predictability}

Both the Brussels I Regulation and the Brussels I Recast contain recitals stating that ' $[\mathrm{t}]$ he rules of jurisdiction should be highly predictable'. ${ }^{108}$ The Brussels I regime has always sought to provide clear rules as to jurisdiction and a straightforward lis pendens procedure for resolving conflicts of jurisdiction. ${ }^{109}$

Indeed, the strict lis pendens rule in Article 29 of the Brussels I Recast ${ }^{110}$ is, and always has been, concerned with the prevention of parallel proceedings and attendant risk of irreconcilable judgments, which are considered to undermine legal certainty and predictability. ${ }^{111}$ The law is focused on preventing parallel proceedings and keeping the system predictable ${ }^{112}$ to the extent that it can be criticised for being overly rigid, encouraging tactical litigation, and for being unduly unfair. ${ }^{113}$

It may indeed be suggested that legal certainty and predictability are as important as mutual trust in international private law. The two seem to go hand in hand in several of the cases concerning mutual trust cited above. ${ }^{114}$

These important principles are undermined by the possibility of parallel arbitration and court proceedings. They are also undermined by the possibility of the enforcement of

106 Dowers, NA, "The Anti-suit Injunction and the EU: Legal Tradition and Europeanisation in International Private Law", 2(4) Cambridge Journal of International and Comparative Law (2013) 960, 972973.

107 Carducci, G, "Arbitration, Anti-suit Injunctions and Lis Pendens under the European Jurisdiction Regulation and the New York Convention", 27 (2) Arbitration International (2011) 171, 173.

108 Recital 15, Brussels I Recast; Recital 11, Brussels I Regulation.

109 Ibid; see generally Brussels I Recast and Brussels I Regulation and specifically the lis pendens rules at Article 29, Brussels I Recast; Article 27, Brussels I regulation.

110 Article 27, Brussels I Regulation; Articles 21-23, Brussels Convention.

111 CJEU, Case C-144/86, Gubisch Maschinenfabrik KGv Giulio Palumbo, [1987] ECR 04861, para 8; Overseas Union, para 16; Gasser, paras 41, 51; Jenard, supra nt 5, 41; Fentiman, R, "Article 27", in Magnus, U and Mankowski, P, eds, Brussels I Regulation (2nd rev ed, Sellier European Law Publishers, Munich, 2012), 582-584.

112 Fentiman, R, "Introduction to Arts 27-30" in Magnus and Mankowski, P, Eds, Brussels I Regulation (2nd rev ed, Sellier European Law Publishers, Munich, 2012), 558-562, 568 (Fentiman, Introduction to Arts 27-30); Layton, Aand Mercer, H, European Civil Practice (2nd ed, Sweet \& Maxwell, London, 2004), 794.

113 Fentiman, Introduction to Arts 27-30, supra nt 112, 569-574; Simons, T, "Cross-border 'Torpedo' Actions. The lis pendens rule in European cross-national legislation", 5/6 The European Legal Forum (2003) 287. For the question of unfairness, see the discussion of potential breach of Article 6 European Convention on Human Rights (or lack thereof) in Gasser, para 56.

114 Gasser, para 72; TNT, para 49. 
set aside arbitral awards, when another arbitral award may subsequently be rendered in the same dispute. ${ }^{115}$ Legal certainty could also be served by implementing rules such as those discussed above, eliminating parallel proceedings by way of a lis pendens rule and requiring the mutual recognition of set aside decisions.

\section{IV.3. The Importance of the Seat of Arbitration}

The New York Convention envisages a relatively important role for the seat of arbitration. This can be seen in the set-aside provision of Article $V(1)(e)$ and in the conflicts rules of Article V(1)(a) and (d). Article V(1)(e) allows refusal of recognition and enforcement when 'The award has not yet become binding on the parties, or has been set aside or suspended by a competent authority of the country in which, or under the law of which, that award was made."116

The majority view is that the phrase 'the country in which, or under the law of which' refers to the juridical seat of arbitration. ${ }^{117}$ This provision therefore gives potential international force to a decision by the courts of the seat of arbitration to set aside or vacate an award. It is at any rate clear that this provision implies an important, supervisory role for the courts of the seat of arbitration, a role which has long been recognised in this area. ${ }^{118}$

The conflict rules in Article V(1)(a) and (d) of the New York Convention also give an important role to the law of the seat of arbitration. These rules place the law of the seat of arbitration second only to the law chosen by the parties in establishing the law applicable to the validity of the arbitration agreement and the procedure to be followed by the arbitral tribunal.

It is clear that the New York Convention implies a relatively important role in the arbitral process for the seat of the arbitration. This makes the seat of the arbitration an appropriate forum to be given preference under the jurisdictional rules suggested above.

\section{Conclusion}

The Brussels I Recast does not provide a satisfactory answer to reconciling the conflict between jurisdiction and arbitration. In particular, the parties are allowed to challenge an arbitration agreement in any Member State. Subject to the national law, parallel proceedings may exist not only between courts but also between courts and arbitral tribunals. An early judgment declaring an arbitration agreement valid may not prevent subsequent proceedings on the same issue or on the merit of the dispute in another Member State. Additionally, a judgment based on the nullity of an arbitration agreement may be recognised and enforced in other Member States irrespective of irreconcilable judgments on ancillary questions in an earlier decision, by the arbitral tribunal, or likely by the recognising State. This attempt to reform the law has been rather unsuccessful.

This article proposes three principles assisting the future reform of this issue, namely, mutual trust, legal certainty and the 'seat' approach. Based on the three principles, it

\footnotetext{
115 See PT Putrabali.

116 [emphasis added].

117 Fox, TJ and Wilske, S, "Article II (3)" in Wolff, R, ed, New York Convention: Convention on Recognition and Enforcement of Foreign Arbitral Awards of 10 June 1959 Commentary (Beck/Hart Publishing, Munich, 2012), 276-277; van den Berg, AJ, The New York Arbitration Convention of 1958 (Kluwer Law International, Alphen aan den Rijn, 1981), 295.

118 van den Berg, supra nt 117, 20.
} 
146 GroJIL 3(1) (2015), 125-146

proposes the mandatory stay lis pendens rule, the seat priority rule, the mutual recognition and enforcement rule and the New York Convention superiority rule. Ancillary questions, such as the validity of an arbitration agreement, shall be included within the scope of the Brussels I regime. Judgments shall benefit from the mutual recognition and enforcement in Member States. This is supported by a mandatory stay lis pendens rule and subject to the priority of the seat of arbitration. If the supervisory court or the arbitral tribunal is seized to decide the same question, priority should be given to the seat of arbitration. Finally, the New York Convention superiority rule provides that any judgment on the merit irreconcilable with the arbitral awards in the New York Convention should not be recognised or enforced under the Brussels I regime. 